\title{
A Case of Malignant Peripheral Nerve Sheath Tumor in Parapharyngeal Space
}

\author{
Hyun Sub Lee, Chang Hee Lee, Sung Min Jin and Sang Hyuk Lee \\ Department of Otorhinolaryngology-Head and Neck Surgery, Kangbuk Samsung Hospital, \\ Sungkyunkwan University School of Medicine, Seoul, Korea
}

\author{
부인두 공간에서 발생한 악성 말초 신경초 종양 1 예 \\ 이현섭 · 이창희 · 진성민 · 이상혁 \\ 성균관대학교 의과대학 강북삼성병원 이비인후과학교실
}

Received December 13, 2011

Revised January 15,2012

Accepted January 27, 2012

Address for correspondence

Sang Hyuk Lee, MD

Department of Otorhinolaryngology-

Head and Neck Surgery, Kangbuk

Samsung Hospital, Sungkyunkwan

University School of Medicine,

78 Saemunan-gil, Jongno-gu,

Seoul 110-746, Korea

Tel $+82-2-2001-2269$

Fax $+82-2-2001-2273$

E-mail entlsh@hanmail.net
The malignant peripheral nerve sheath tumor is an extremely rare soft tissue sarcoma. It is a highly malignant sarcoma, which is locally invasive, frequently leading to multiple recurrences and eventual metastatic spread. The peak incidence of disease is known to occur sporadically between the age of $20 \mathrm{~s}$ and $50 \mathrm{~s}$, and is usually associated with the neurofibromatosis type I. In human body, the trunk and extremities are the most commonly involved sites, with only $8-14 \%$ of all lesions appearing in the head and neck region. We present a case of malignant peripheral nerve sheath tumor involving the right parapharynx in a 48 -year-old patient who complained of headaches in the right parietal area and of dysphagia that aggravated over a month. After surgery, tumor was finally diagnosed as malignant peripheral nerve sheath tumor by histopathologic examinations. The authors report a case of malignant peripheral nerve sheath tumor in the right parapharynx with a review of the literature.

Korean J Otorhinolaryngol-Head Neck Surg 2012;55:181-4

Key Words Malignant peripheral nerve sheath tumor $\cdot$ Parapharynx $\cdot$ Neurofibrosarcoma Malignant schwannoma $\cdot$ Malignant neurilemmoma.

\section{서 론}

악성 말초 신경초 종양(malignant peripheral nerve sheath tumor)은 신경섬유 육종(neurofibrosarcoma), 악성 슈반 세포 종(malignant schwannoma), 신경성 육종(neurogenic sarco$\mathrm{ma}$ ), 악성 신경초종(malignant neurilemmoma) 등의 여러 이 름으로도 불리며 자율신경, 뇌신경 및 말초신경의 신경주위 섬유아세포(fibroblast)나 신경집세포(Schwann's cell) 같은 신경초(nerve sheath)를 구성하는 세포로부터 발생하는 것 으로 알려져 있다. ${ }^{1)}$ 모든 연부조직의 육종 중에서 약 $5 \%$ 를 차 지하고 있으며 신체의 어느 부위에서나 발생할 수 있지만 주 로 체간이나 사지에서 발생하는 것으로 알려져 있다. ${ }^{2)}$ 두경부 영역에서 발생되는 경우는 드물어 전체 악성 말초 신경초 종
양의 $10 \%$ 미만에서 보고되고 있으며, 국내에서는 부비동, 비 강, 안와, 후두에서 증례보고 형식으로 보고되어 왔으며 부인 두 공간에서의 발생은 보고된 바가 없다. ${ }^{3-6)}$ 약 $70 \%$ 에서는 제1형 신경섬유종증과 관련이 있으며 $30 \%$ 에서는 산발적으 로 발생하는 것으로 알려져 있다. ${ }^{1)}$ 저자들은 신경섬유종증을 동반하지 않은 48세 남자 환자에서 우측 부인두 공간 내에서 발생한 악성 말초 신경초 종양을 경험하였기에 문헌고찰과 함 께 보고하는 바이다.

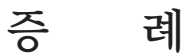

48세 남자 환자가 내원 1 개월부터 시작된 우측 두정엽 부위 의 두통과 연하 곤란을 주소로 내원하였다. 과거력상 다른 

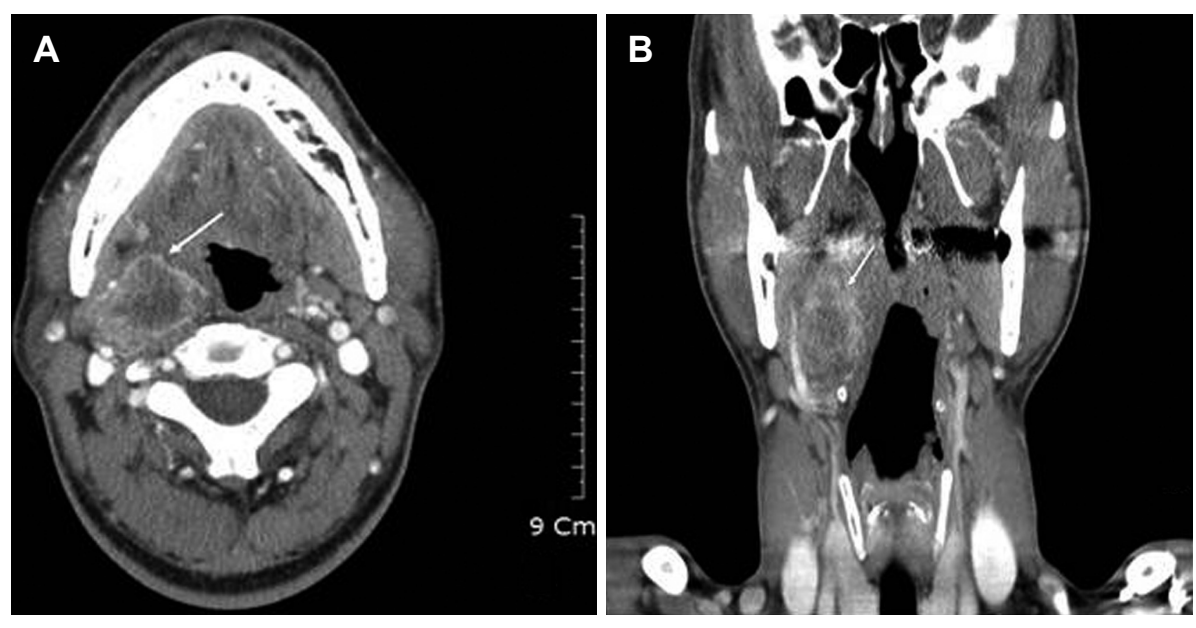

Fig. 1. Axial (A) and coronal $(B)$ neck CT shows the $3.8 \times 2.5 \times 5.2 \mathrm{~cm}$ sized well-defined, heterogenously enhancing mass. Tumor is shifting right posterior pharyngeal wall medially. CT: computed tomography.
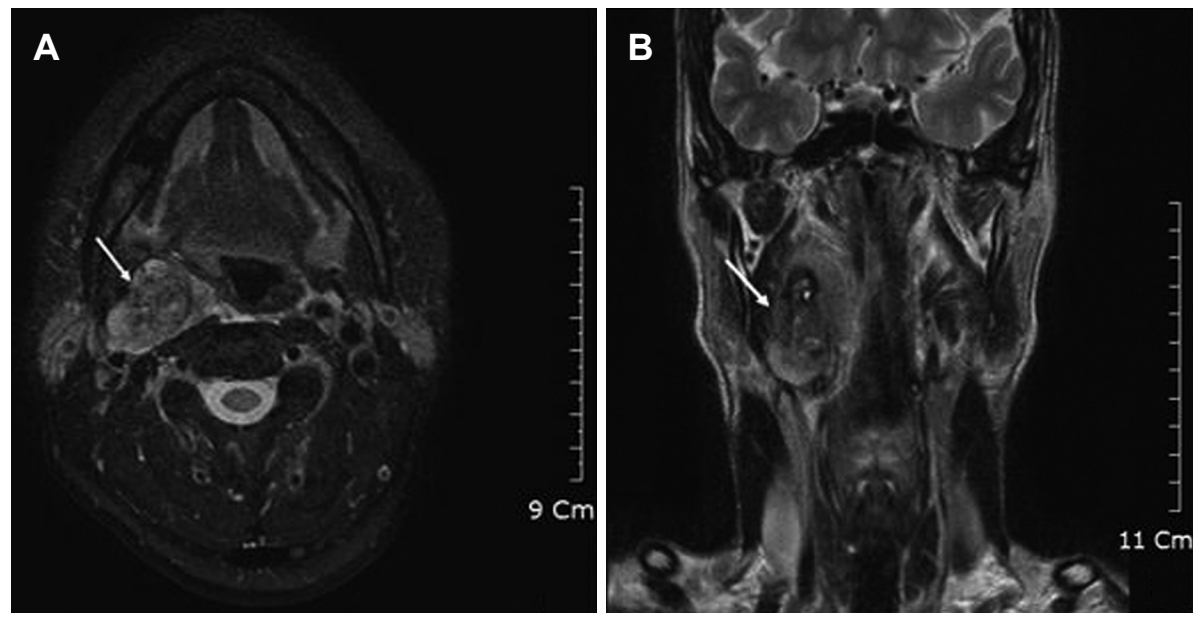

Fig. 2. Axial (A) and coronal (B) T2W neck MRI demonstrates significant homogenous peripheral enhancement with central calcification. Tumor does not show evidence of invasion of adjacent structures. MRI: magnetic resonance image.

전신 질환의 병력은 없었으며 가족력상 특이병력은 없었다. 문 진상 1달 전부터 지속된 두통 및 연하통을 호소하였으며 내 원 2주 전부터는 목의 이물감 및 연하곤란을 호소하고 있었 다. 내원 당시 환자는 진통제에 잘 반응하지 않는 극심한 두 통을 호소하고 있었고 내원 전 타 병원에서 시행한 뇌 전산화 단층촬영상 특이소견은 없는 상태였다. 이학적 검사상 우측 부 인두강에서 기원한 종물로 인해 후인두벽이 내측으로 돌출된 소견을 관찰할 수 있었으며 목젖의 편위는 관찰되지 않았다. 경부의 촉진상 만져지는 종물은 없었으며 동반된 림프절 종 대도 관찰되지 않았다. 시행한 후두내시경 검사상 성대의 마 비는 관찰되지 않았다.

경부 전산화 단층 촬영에서 $3.8 \times 2.5 \times 5.2 \mathrm{~cm}$ 크기의 상대적 으로 비균질 음영을 보이는 종물이 우측 부인두 공간의 후경 상 공간에서 관찰되었고 주변 조직과의 침범소견은 관찰 되 지 않았다(Fig. 1). 경부 자기공명촬영 영상에서도 T2 영상에 서 우측 부인두 공간의 후경상 공간 내에 내부의 석회화 변성 을 동반한 비균질한 신호강도를 보이는 종물이 관찰 되었다. 종물은 우측 비인두벽을 밀고 있으나 주변 근육에 대한 침범

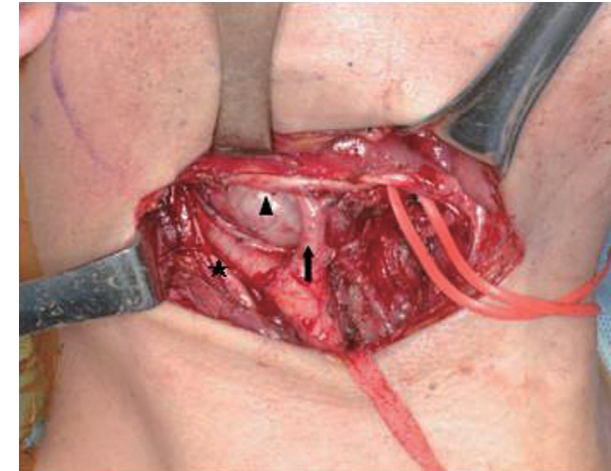

Fig. 3. Operative finding of tumor shows a ovoid smooth mass without adhesion or invasion of adjacent structure (triangle: hypoglossal nerve, star: internal carotid artery, arrow: external carotid artery).

은 관찰되지 않으며 우측 내경동맥과 연접하고 있으나 침범 소견은 관찰되지 않았다(Fig. 2). 초음파 유도하 세침흡입검 사상 신경초종으로 진단되었고 수술 전 검사상 신경의 기원은 밝혀내지 못한 상태에서 빈도상 우측의 미주 신경 혹은 경부 교감신경절에서 유래하였을 신경초종 가정하에 경부 접근을 통한 종물의 제거 수술을 계획하였다. 수술 당시 종물은 비 
교적 잘 박리되었으며 주변의 신경이나 혈관과의 유착은 관 찰되지 않은 상태로 $4 \times 4 \mathrm{~cm}$ 크기의 종물을 적출할 수 있었 다(Figs. 3 and 4). 수술 후 환자는 우측 성대마비를 호소하 여 미주신경에 기원한 종양임을 추정할 수 있었다. 조직 현미 경 소견상 종양은 섬유성 조직으로 구성된 피막으로 둘러싸 여 부분적으로 종양 내 괴사가 관찰되었으며 활발한 세포 분 열과 높은 세포밀도를 보이고, 다형성의 비정형적인 핵을 가 진 신경초종 패턴(schwannoma pattern)으로 관찰되고 있 었다. 면역 조직화학 염색상 S-100 단백질 양성, vimentin 양 성, neuron-specific enolase(NSE) 양성, 그리고 desmin 음 성 반응을 보여 고등급의 악성 말초 신경초종으로 확진되었 다(Fig. 5).

수술 후에도 환자의 극심한 두통은 호전되지 않았고 마약 성 진통제에도 반응하지 않는 양상을 보였다. 추가적인 방사 선 치료를 계획 도중 시행한 양전자방출단층촬영상 척추의 골전이 및 내경정맥 림프절의 전이소견을 보이고 있었다. 방 사선 치료 중 환자는 전신의 쇠약감으로 방사선 치료의 휴식 과 치료를 반복하다가 $3900 \mathrm{cGy}$ 의 방사선 치료를 시행하고 악액질 및 방사성 폐렴으로 수술 4개월 후 사망하였다.

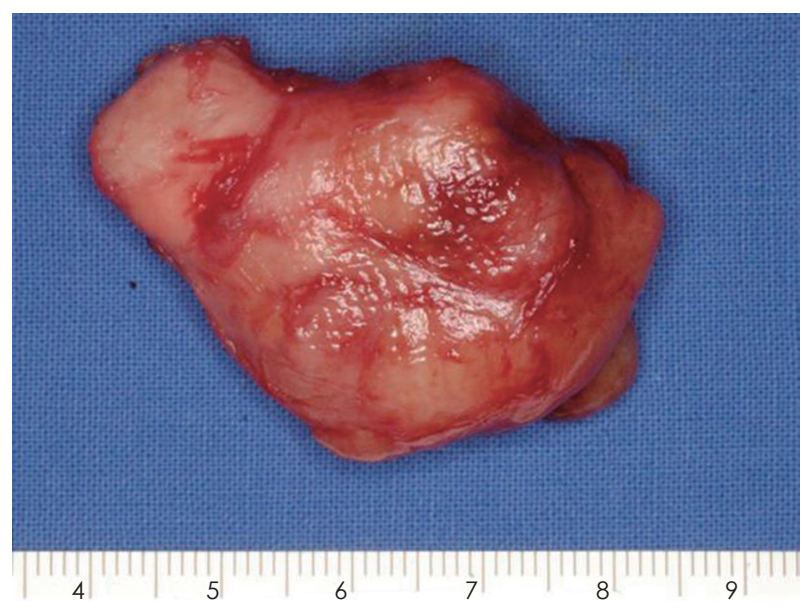

Fig. 4. Gross finding of the excised specimen shows an ovoid yellow-whitish mass with fibrous smooth surface.

\section{고 찰}

악성말초 신경초 종양의 발생률은 대개 10 만 명당 1 명으로 보고되고 있으며 연령분포를 보면 모든 연령에서 발생할 수 있으나 소아에서는 극히 드물고 20대에서 50대 사이에 주로 발생하며 남녀의 차이는 거의 없다. ${ }^{7-9)}$ 상 염색체 우성으로 유 전성을 보이는 신경섬유종증 1형과 관련이 있어 전체 종양의 약 $70 \%$ 에서 동반되며 $30 \%$ 에서는 산발적으로 발생한다. ${ }^{1)}$ 신 경섬유종증을 동반한 경우는 발생연령이 더 빠른 것으로 알 려져 있으며 예후는 산발적으로 발생한 악성 말초 신경초 종 양보다 안 좋은 것으로 보고되고 있다. ${ }^{10)}$ 병인은 불분명하나 일반적으로 방사선 조사가 위험인자로 알려져 있다. ${ }^{89}$

주된 증상으로는 점차로 커지는 무통성의 종물이 가장 흔 하며 종양의 주변 구조물을 압박하여 증상을 나타내거나 침 범된 신경의 지배 부위의 비특이적인 통증이나 이상감각, 마비 등이 나타날 수 있다. ${ }^{8}$ 본 증례에서는 마약성 진통제에도 잘 반응하지 않은 극심한 이환부위를 따른 두통을 호소하였다. 통증이 발생하는 기전은 종양의 팽창으로 인한 주변의 통증 에 민감한 구조물의 견인 및 압박이나 Substance P, calcitonin gene related peptide 같은 신경 전달물질이 통각신경섬유들 (nociceptive nerve fiber)을 자극하여 통증이 유발되는 것으 로 알려져 있다. ${ }^{11)}$ 수술로서 종양을 제거한 후에도 두통은 일 시적인 경감양상을 보이다 다시 지속되는 양상을 보였는데 이 는 종양에 의한 견인 및 압박 효과보다는 신경 전달물질과 같 은 다른 원인에 의하여 통증이 유발되었을 것으로 생각된다.

육안적으로 종양은 회백색의 구형 또는 방추형으로 비교적 단단한 형태로 관찰되며 국소적인 괴사가 동반될 수 있다. 광 학현미경 소견에서는 과염색질이면서 다발성의 방추상세포 가 밀집된 양상 또는 속상 배열의 형태로 보이며, 이 방추상세 포들은 활발한 세포 분열과 비정형적인 핵을 가진다. ${ }^{812)}$ 면역 조직화학염색상 vimentin과 S-100 단백에 양성반응을 보이 며 상피세포, 신경내분비 또는 근육세포의 분화와 관련된 항 체에 음성반응을 보이는 경우 악성 말초 신경초 종양으로 진단

Fig. 5. Histopathologic findings. Tumor cells showed packed atypical spindle cells in H\&E stain $(\times 400)(A)$. Immunohistochemical stains for protein S-100 showed strong positivity $(\times 400)(B)$.
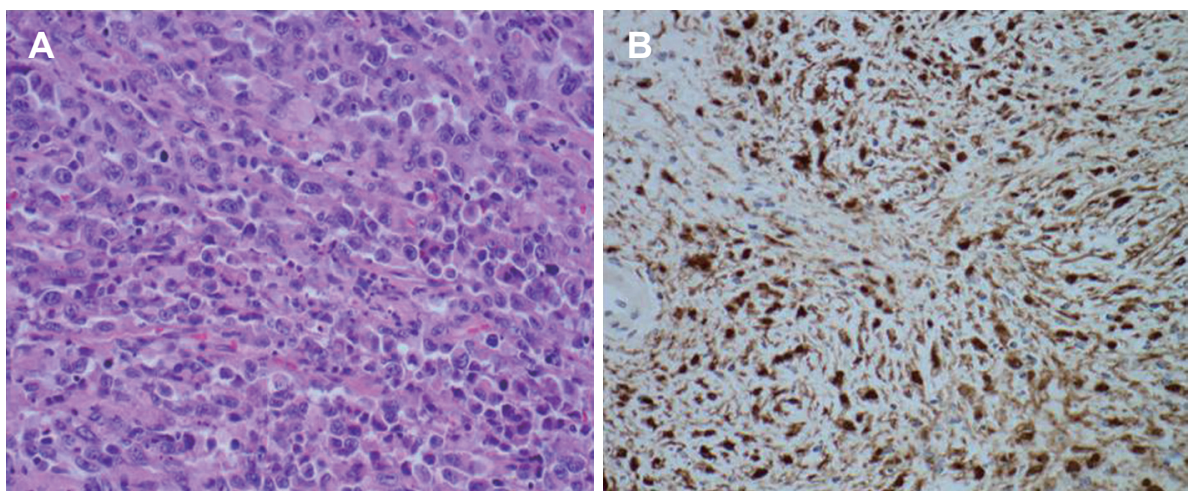
할 수 있다. ${ }^{14)}$ 본 증례의 경우는 S-100 단백질, vimentin, NSE 에 양성을 보였으며, desmin에 음성 반응을 보여 진단할 수 있었다.

전산화단층촬영과 자기공명영상은 병의 파급 정도 및 중 요 기관의 침범 유무와 병기 결정에 필요하다. 전산화단층촬 영에서 경계는 비교적 명확하고 비균질한 음영을 보이는 경우 가 많으며 자기공명영상에서도 비균질한 신호강도를 보이는 종괴로 나타나게 된다. 조영증강영상에서 종괴내 저밀도 음 영은 괴사 조직으로 의미하며 악성도가 높음을 시사한다. ${ }^{15)}$ 악성 말초 신경초 종양의 주된 치료방법은 광범위한 외과적 절제술이고 신경에 이환된 경우에는 신경과 분리해서 절제 할 수 없으며 해당신경의 한 구간을 절제해야 한다. 림프절전 이의 가능성이 적기 때문에 예방적 림프절 절제술은 보통 시 행되지 않는다. ${ }^{12)}$ 과거에는 방사선 저항성인 것으로 알려져 왔 으나 최근 Basso-Ricci 등의 보고에 따르면 단독 수술보다는 수술 후 병합치료로 고용량의 방사선 치료가 생존율을 높인 다고 하였다. ${ }^{8)}$ 따라서 국소 재발률을 줄이기 위해서나 종양의 완전절제가 어려운 경우, 수술 후 절제연이 불확실한 경우 추 가적인 방사선 치료를 병합하며 수술이 불가능한 경우는 방사 선 치료가 1 차 치료로 시도되고 있다. 항암요법의 효과는 아직 불확실하다. ${ }^{12)}$

일반적인 전이 양상은 다른 육종처럼 빠르게 주위 조직으 로 광범위하게 침투하는 양상을 보이며 림프관을 통한 전이 보다는 주로 혈관을 통한 전이가 흔하다. 약 16 68\%에서 폐, 늑막, 간, 골 등 다른 장기로 전이되며 그 중 폐 전이가 가장 흔 한 것으로 알려져 있다. ${ }^{89}$ 예후는 불량하여 Wanebo 드이) 은 5 년 생존율이 $43.7 \%$ 이며 환자의 나이, 종양의 크기, 위치, 절 제연, 신경섬유종증 동반여부 등이 예후인자라고 하였다. 악 성도의 기준은 세포의 밀집도, 핵의 다형성 및 역형성, 유사분 열능, 미세혈관 증식 및 괴사의 정도에 따라 결정된다. 두경 부 영역의 5년 생존율은 보고자마다 다르나 대개 15 34\%로 보고되고 있다. ${ }^{37,8)}$

악성 말초 신경초 종양은 두경부 영역에서 빈도가 극히 드문 질환으로 임상적, 조직학적으로 진단이 매우 어려운 질환이 며 본 증례와 같이 수술 전 시행한 검사상 양성종양으로 진단 이 된 후에도 최종적으로 악성종양으로 진단될 수 있기에 주
의를 요한다. 저자들은 두경부에 발생한 악성 말초 신경초 종 양 1 예를 경험하였기에 보고하는 바이며, 두경부에 발생한 종 양의 감별시 염두에 두고 빠른 진단과 치료가 필요하리라 생 각한다.

\section{REFERENCES}

1) Das Gupta TK, Brasfield RD. Solitary malignant schwannoma. Ann Surg 1970;171(3):419-28.

2) Marx RE, Stern D. Oral and Maxillofacial Pathology: A Rationale for Diagnosis and Treatment. 2nd ed. Illinois: Quintessence Publishing Co., Inc.;2003. p.475-7.

3) Kim HJ, Kim JY, Kim CH, Yoon JH. A case of malignant peripheral nerve sheath tumor on paranasal sinus. Korean J Otolaryngol-Head Neck Surg 2005;48(2):263-6.

4) Cho SH, Kim HT, Yoo WJ, Kim MS. Malignant peripheral nerve sheath tumor of larynx. Korean J Otolaryngol-Head Neck Surg 1997; 40(3):450-6.

5) Yoon YH, Roh JL. Malignant peripheral nerve sheath tumor arising from plexiform neurofibroma in neurofibromatosis type I. Korean J Otolaryngol-Head Neck Surg 2005;48(4):551-3.

6) Lee MO, Jeon C, Suh YL, Woo KI, Kim YD. A case of malignant peripheral nerve sheath tumor of the orbit. J Korean Ophthalmol Soc 2009;50(9):1409-13.

7) D'Agostino AN, Soule EH, Miller RH. Primary malignant neoplasms of nerves (malignant neurilemomas) in patients without manifestations of multiple neurofibromatosis (von Recklinghausen's disease). Cancer 1963;16:1003-14.

8) Minovi A, Basten O, Hunter B, Draf W, Bockmühl U. Malignant peripheral nerve sheath tumors of the head and neck: management of 10 cases and literature review. Head Neck 2007;29(5):439-45.

9) Loree TR, North JH Jr, Werness BA, Nangia R, Mullins AP, Hicks WL Jr. Malignant peripheral nerve sheath tumors of the head and neck: analysis of prognostic factors. Otolaryngol Head Neck Surg 2000;122(5):667-72.

10) Ducatman BS, Scheithauer BW. Postirradiation neurofibrosarcoma. Cancer 1983;51(6):1028-33.

11) Goffaux P, Fortin D. Brain tumor headaches: from bedside to bench. Neurosurgery 2010;67(2):459-66.

12) Ducatman BS, Scheithauer BW, Piepgras DG, Reiman HM, Ilstrup DM. Malignant peripheral nerve sheath tumors. A clinicopathologic study of 120 cases. Cancer 1986;57(10):2006-21.

13) Wanebo JE, Malik JM, VandenBerg SR, Wanebo HJ, Driesen N, Persing JA. Malignant peripheral nerve sheath tumors. A clinicopathologic study of 28 cases. Cancer 1993;71(4):1247-53.

14) Daimaru Y, Hashimoto H, Enjoji M. Malignant peripheral nervesheath tumors (malignant schwannomas). An immunohistochemical study of 29 cases. Am J Surg Pathol 1985;9(6):434-44.

15) Stull MA, Moser RP Jr, Kransdorf MJ, Bogumill GP, Nelson MC. Magnetic resonance appearance of peripheral nerve sheath tumors. Skeletal Radiol 1991;20(1):9-14. 